\begin{tabular}{|c|c|}
\hline \multirow{3}{*}{ 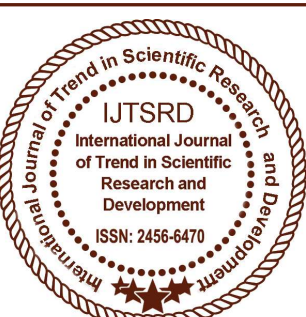 } & $\begin{array}{l}\text { International Journal of Trend in Scientific } \\
\text { Research and Development (IJTSRD) }\end{array}$ \\
\hline & International Open Access Journal \\
\hline & ISSN No: 2456 - 6470 | www.ijtsrd.com | Volume - 2 | Issue - 3 \\
\hline
\end{tabular}

\title{
School Environment and Inclusive Educational Settings: Policy Implications and Mitigation Strategies Emerging from the South West Region of Cameroon
}

\author{
Ambei Ruhama Faizefu Ph.D. \\ Department of Educational Psychology, \\ Faculty of Education, University of Buea, Cameroon
}

\section{ABSTRACT}

The Cameroon government have not enforced Fullservice schools to provide quality education to all learners through flexibility to meet the full range of learning needs. Full-service schools are institutions that strive to transform themselves, proactively addressing the barriers to learning and increasing participation of the learners and educators in the teaching and learning process. This can be achieved by enhancing the flexibility of teaching and learning methods used. This conceptual and policy paper therefore focused on the school environment used in inclusive classrooms to accommodate diversity. The appropriateness, adequacy and ease of use of the physical infrastructures were assessed using domains like height, Width space, Lay-out or arrangement, flexibility, slope/ gradient, smoothness, level or flat, non-slip, designated spaces, safety, adaptations, signage, easy to read or use, shape, clear of obstacles, alternative entrance, bridging differences in surface levels, outward-swinging and taking part. The study basic pre-supposition was that inaccessible physical infrastructure was one of the major barriers that hindered the performance of students with disabilities in schools in Cameroon. Different physical infrastructures were assessed including furniture, classrooms, Pathways, Parking, Ramps, Entrances, Handrails, Furniture, toilets, bathrooms, Accessories and controls, Signs, playfields, Doors, Corridors Benches, chairs, tables, bookshelves, entrances safety guards/ rails etc. some recommendations were advanced for policy implementation to improve the school/learning environment of all schools as a strategy to meet the diverse needs of every student in an inclusive educational setting.

Keywords: Development, Inclusive Education, Cameroon and School Environment

\section{INTRODUCTION}

Today there are a number of resolutions concerning the rights to education for all children. The focus of this study is on inclusive education. This article reviews the major resolutions which entail principles regarding education for all, and foremost their focus on rights to education for persons with disabilities and inclusive education. Through the major declarations that are mentioned below, concerning rights to education, nations are urged to fast forward their actions of providing equal access to education for all. Education is agreed upon to be a key factor to human and individual development, and thus implicitly for a nation's economical growth. Minority groups such as persons with disabilities are in many countries the last to receive proper education; this is also true in Cameroon which is the case study. Denying persons with disabilities the possibility to be given education deprives them of a fundamental right, and prevents them from achieving basic skills that are necessary for meaningful participation in their societies. Therefore this article profiles the development of inclusive education in Cameroon with more focus on the efforts that have been made to improve on the school environment as a major determinant in the implementation of inclusive educational practices for 
optimal educational participation of students with disabilities.

\section{Background of the study}

The struggle for achieving education for all was for the first time recognised in the Universal Declaration of Human Rights (UN,1948). Through this declaration and other various initiatives from the international community, all states with few exceptions are signatory and thus committed to resolutions that in different ways secure rights, protect the people of the state, their resources and their voices, regardless of traits such as race, religion, caste, gender, health or age. Education as a right for all is stated in Article 26 of the 1948 Human Rights Declaration:

Everyone has the right to education. Education shall be free, at least in the elementary and fundamental stages. Elementary education shall be compulsory... Education shall be directed to the full development of the human personality and to the strengthening of respect for human rights and fundamental freedoms. It shall promote understanding, tolerance and friendship among all nations, racial or religious groups, and shall further the activities of the United Nations for the maintenance of peace (UN, 1948:26).

Article 26 may be perceived as the beginning of a still ongoing international era to secure basic education for all children. The goals to provide education for all children are stated clearly in the below mentioned declarations, which is perceive as the most relevant documents in the context of this study. Chronological presentation of relevant international documents demonstrate the international, regional and national commitments to enforce inclusive educational policies. This include;

> 1948: Universal Declaration of Human Rights

$>$ 1982: UN The World Programme for Action Concerning Disabled Persons

$>$ 1989: UN Convention on the Right of the Child

$>$ 1990: The World Declaration on Education For All

$>$ 1993: UN Standard Rules on Equalization and Opportunities for Persons with Disabilities

$>$ 1994: Salamanca Statement and Framework of Action on Special Needs Education
$>$ 2000: World Education Forum (EFA) and Millennium Development Goals

$>$ 2001: EFA Flagship: Education for persons with disabilities: Towards Inclusive

2007: UN Convention of the Rights of Persons with Disabilities

Change is never easy, as it involves a process that takes time, sometimes up to several years, rather than a single occurrence or event (Villa \& Thousand, 1992). It involves more than just programmes, material, technology or equipment, but is primarily about individuals in an established system. It is highly personal, affects people, is viewed differently by each participant and requires personal growth. Yet change is inevitable when innovative practices demonstrate greater effectiveness than past services (Ryndak \& Alper, 1996). For years, education systems worldwide have provided special education and related services to students with special needs (Ryndak \& Alper, 1996. As discussed in most literature, reform in education has led to a move away from segregation of learners with disabilities in special classes toward the inclusion of such learners in general education.

In spite of the initiation of new policies and curricula, this process of change has raised numerous questions about the role and responsibilities of school environment and school personnel in providing appropriate education for all learners enrolled in the ordinary schools (Daane \& Beirne-Smith, 2001). As agents of change in the education situation, it is not surprising to find that teachers have many concerns about the implementation of these new initiatives (Forlin, 1998). The reason for this is that 'change' is difficult to bring about in schools and classrooms as it requires simultaneous reforms in professional development, curriculum, learner support services, classroom management, along with a change in teacher attitudes, beliefs, values and knowledge. (Fullan \& Miles, 1992 in Weiner, 2003; Reynolds, 2001).

It is specifically the last-mentioned aspects that may act either to facilitate or constrain the implementation of inclusive policies, as the success of such a challenging programme depends on the co-operation and commitment of those most directly involved (Avramidis, Bayliss \& Burden, 2000). The teacher's knowledge, beliefs and values are brought to bear in creating the effective learning environment for pupils, 
and thus they are a crucial influence in the development of an inclusive system (Reynolds, 2001).

Since the mid 1970's there has been a growing body of research and practice concerning the accessibility of the environment for persons with disabilities that has led to design guidelines, standards and codes (Steinfield and Danford, 1999). This has led to recommendations and norms on which to base when making major decisions in social policy and design practice. Some of the guidelines are clearly indicated by UN (2006) Convention on The Rights of Persons with Disabilities which provides for the rights of access to services for persons with disabilities. Shakespeare (2006) suggests that, the mission of removing barriers like inaccessible physical infrastructure caused changes in the environments of some countries which wholly adopted the rights of persons with disabilities like the United States of America, where the removal of such barriers was legislated by the 1973 Rehabilitation Act (section 504) and the 1990 America with disabilities Act. In 1993 as a result of the International Year of Disabled Persons in 1981 and the United Nations Decade of Disabled Persons from 1983 to 1992, Member States of the United Nations agreed on a new international document to focus worldwide attention on the need for equal rights and opportunities for persons with disabilities - The Standard Rules on the Equalization of Opportunities for Persons with Disabilities (United Nations, 1993).

Research has shown that, there still exists community's persistent assumption that persons with disabilities' expectations, participation and performance should be lower. That is the reason why community is many times surprised when they find that persons with disabilities can perform. Block (2002) provides different perceptions by society regarding persons with disabilities, some of which exist to date as follows: sub-human organism according to beliefs of the nineteenth and twentieth century; menace to society implying a danger that can harm others; object of pity in need of charity; sick i.e., their disability is regarded as illness. It is upon this perception of sickness that the medical model evolved because it emphasizes cure, treatment and diagnosis and viewed disability as a medical problem situated within the individual, against the current social model, that define disability as a social construction (UNICEF, 2008). The social model assumes that it is society that disables individuals with physically impairment through creation of barriers that exclude them. It should be noted that, while disability can be a result of sickness, many persons with disabilities are not sick. Other perceptions include the following: a burden to society by draining resources without contributions; object of ridicule, a form of joke for amusing others; the least of God's people who should be poor and oppressed; eternal child by being infantilized i.e., treating an adult like a child; a bizarre and grotesque i.e., viewed as freak or frightening sight. Anderson (2009) provides that, due to lack of scientific answers, people in developing nations like Cameroon have devised superstitious or mythological explanations for disability, such as a lack of proper reverence for one's ancestors, broken taboos, witchcraft, evil spirits, or individual or parental sin, thus creating erroneous views leading to prejudicial attitudes, which often result in exclusion of persons with disabilities in the community including educational institutions.

Equity and social justice in secondary schools consists of addressing the individual needs of all students including those with disabilities. Unfortunately, despite the international and national policies, many teachers and school administrators do not provide for the individual needs of students with disabilities because they believe that they ought to be educated in the special education system. This creates lack of a sense of belonging for students with special needs in school society. Provision such as accessible physical infrastructure for example, is a pre-requisite for persons with physical disabilities to equally and fully participate in Education. The UN (1993) Standard Rules on the Equalization of Opportunities for Persons with Disabilities emphasizes full participation and equalization of opportunities. UN (2006) Rule 6 concerning education provides that, States should:

Recognize the principle of equal primary, secondary and tertiary educational opportunities for children, youth and adults with disabilities, in integrated settings. ....... adequate accessibility and support services, designed to meet the needs of persons with different disabilities, should be provided. ....... In States where education is compulsory it should be provided to girls and boys with all kinds and all levels of disabilities, including the most severe.. (P. 4). 
Accessible physical infrastructure can provide equal access to education for all. The removal of physical barriers is one way of including persons with disabilities in education. Accessible physical infrastructures in school results in equality because it benefits all students and not only persons with physical disabilities. The UN (2006) Convention on the Rights of Persons with Disabilities states that, measures should be undertaken to eliminate obstacles and barriers to indoor and outdoor facilities including schools, medical facilities and workplaces. These would include not only buildings, but also footpaths, curb cuts, and obstacles that block the flow of pedestrian traffic.

UN (2009) estimate of Cameroon's total population is 19,958,351. Estimates by the World Health Organization (2005) indicate that, there are 1.6 million people with disabilities in Cameroon. Unfortunately, this is not gender segregated. By 2011, Cameroon had signed but not ratified the Convention on the Rights of Persons with Disabilities (CRPD) and its Optional Protocol, The International Disability Alliance (IDA, 2011). Cameroon's poverty reduction strategy paper published by IMF (2010) indicate the government's continued establishment of specialized structures for persons with disabilities in order to reduce their dependence through easing access to buildings as well as financial support. However, Mbangwana (2011) argue that, despite the drafting of a practical guide on persons with disabilities' access to infrastructure and buildings that are public or open to public and the creation of partnerships to enhance the attendance of children with disabilities, few governments have put these plans in practice.

The Cameroon Constitution was approved by referendum in 1972 and revised in January 1996. This constitution guarantees the rights of all its citizens amongst which are persons with disabilities. Article 18 Section 4 of Law No. 96-06 of The Cameroon Constitution (1996) stipulates that: The aged and the disabled shall also have the right to special measures of protection in keeping with their physical and moral needs. Further, Cameroon's Article 3 (1 and 2) of the 1983 law, forbids all forms of discrimination towards persons with disabilities. The law of 1983 with its degree of application relaxed measures concerning the age limits for persons with disabilities to enrol in school. A study by Mayer (2007) on the rights of persons with disabilities in Cameroon provides that, Article 5 (3) of the 1990 decree for example stipulates that: "pupils and students with disabilities are authorized to repeat a current class twice if the failures in the examinations are caused by the difficulties related to their physical or mental state". The Ministry of Social Affairs is the principal government structure that is charged with the responsibility of addressing issues concerning persons with disabilities in Cameroon. Within this Ministry, there exists a department in charge of the promotion and protection of the rights of persons with disabilities.

\section{Table 1. Proportion of children with at least one} impairment according to type in Cameroon.

\section{\begin{tabular}{l|l} 
TYPE OF & Percentage of children 2-9
\end{tabular}}

\begin{tabular}{l|l} 
DISABILITY & years \\
\hline
\end{tabular}

\begin{tabular}{|l|l|}
\hline Development & 3 \\
\hline Vision & 2 \\
\hline Hearing & 3 \\
\hline Understanding & 4 \\
\hline Movement & 2 \\
\hline Crisis/Fits & 4 \\
\hline Learning & 3 \\
\hline Speaking & 7 \\
\hline Mental & 6 \\
\hline TOTAL & 23 \\
\hline Source:
\end{tabular}

Source: MICS2 2000-01 (Loaiza and Cappa, 2005).

Loaiza and Cappa's (2005) Disability via Household Surveys report on Cameroon indicate that, 23 percent of the children 2-9 years were identified by their caretakers / parents to have at least one impairment. The commonest type of disability in Cameroon is related to spoken communication $(7 \%)$ followed by mental impairment $(6 \%)$; while mobility and vision were the least $(2 \%)$.

According to Rioux, Marks and Basser (2011) a study on the Rights of persons with disabilities in Cameroon indicates that, the law of 1983 and its decree of application provide regulation and facilities to enhance the accessibility of persons with disabilities to certain institutions. However, Article 35 stipulates that "in the domain of studies and social accommodations, the public authorities concerned should, allocate within their programs, a proportion of special accommodations for persons with disabilities who use wheel chairs or who suffer from mobility problems". Article 39 of the same decree holds that "Public places, institutions and the entire residential estates should have as much as possible, reserved parking lots, public toilets, special telephone booths 
and equipment's adapted to the physical conditions of persons with disabilities. They have to be in-line with the accessibility standards as demanded by article 37 and 38 as cited above". Unfortunately, Mayer (2007) study on the Rights of persons with disabilities in Cameroon indicates that, although this decree was promulgated 17 years ago, no action has been taken in implementing the recommendations. There is lack of standard legal provisions to facilitate full enjoyment of the rights to comfortable and secured environment because persons with physical impairment are not considered during the construction of physical infrastructures in Cameroon (Mayer, 2007). The practice is uncertain for example families, sometimes the society in general including educational institutions, show little concern towards persons with disabilities (Mayer, 2007). A report on Cameroon by Peace corps (2014) indicate that, while there is a large population of Cameroonians with disabilities including physical impairment, accommodation and care for them is done informally and within the family or community due to limited infrastructure to accommodate them.

\section{Statement of the Problem.}

The goal of inclusive education is to provide the most appropriate education for all children in the most enabling school environment. The end result of inclusive education, if successfully implemented, is to get all children together whether with or without disabilities in the same classroom. To achieve such a goal, all stakeholders must work together; professionals, parents, administrators, and the political class at a level and in a way that the inclusive agenda can be planned and implemented successfully. However, in spite of the schools admitting some learners with disabilities, they continue to experience a number of challenges. In some schools parents are even opposed to inclusive education. This study therefore sought to assess Cameroon School environment to determine if they are enabling for students with disabilities as well as investigate the challenges facing the successful implementation of inclusive education in Cameroon through a sample of selected schools in the South West Region. This conceptual paper is aimed at pointing out policy gaps in terms of lack of stakeholder's responsibility to ensure optimal inclusive educational practices in terms of providing conducive learning environment.

An overview of Inclusive Education in Cameroon Schools.
The philosophy of inclusive education has been embraced by many governments for its purposeful benefits to learners with disabilities. Inclusion is seen as a process of addressing and responding to the diversity of needs of all learners through increasing participation in learning, cultures, and communities and reducing exclusion within and from education. UNESCO (2005) states that inclusion, ,involves changes and modifications in content, approaches, structures and strategies, with a common vision which covers all children of the appropriate age range and a conviction that it is the responsibility of the regular system to educate all children." historically, the concept of inclusive education has its origin in special education. The development of the field of special education provision, over the years, has evolved through a series of stages during which different strategies have been explored and practiced in order to respond to the needs of children with disabilities and students who experience difficulties in learning. There was segregation where children with disabilities were educated in category schools. Each school focused on a particular disability. It was followed by other philosophies which included least restrictive environment, integration and mainstreaming (Beaur and Shea, 1997). Exclusion policies practiced all over the world, Kenya included, of persons with disabilities have greatly influenced the rise of the philosophy of inclusive education.

Exclusion from meaningful participation in the economic, social, political and cultural life of their communities has been the norm. UNESCO (2005) estimates that there are over 80 million children in Africa who are not attending school. Among these children, the majority are those with disabilities. Whereas the reasons for learners without disabilities being out of school can easily be deduced and addressed, „Current strategies and programmes have not been sufficient to meet the needs of children and youth who are disabled, vulnerable to marginalization or exclusion. Past efforts have consisted of specialized programmes, institutions and specialist educators. The unfortunate consequence of such efforts, although well intended, has often been further exclusion ${ }^{\text {ee }}$ (UNESCO, 2005). Education is key to economic, social and political development of a country and for individual development and functionality, regardless of barriers of any kind, physical or otherwise. „Therefore disability of any kind (physical, social and/or emotional) cannot be a disqualifier ${ }^{\text {ce }}$ (UNESCO, 2005). 
Inclusion therefore attempts to address the different needs of all children, whether with disability or special need or none in the same classroom or school. UNESCO (2005) views inclusion as ,a dynamic approach of responding positively to pupil diversity and of seeing individual differences not as problems, but as opportunities for enriching learning. "e Waldron (1996) argues that ,staying with their class should remove some of the stigma these students feel from peer reactions as well as ensuring they do not miss important instruction while participating in pull-out programmese $^{\text {ee }}$ Learners without disabilities are usually given remedial lessons when they miss classes but the same cannot be said of learners with disabilities.

The principles of inclusion are well captured in major international declarations which include the Universal Declaration of Human Rights (1948) which stated clearly that education is a human right and that „everyone has the right to education (article 26). Everyone here include those with disabilities or special needs. Article 23 of the Convention on the Rights of the Child (1989) also stated that the child has the right to ,effective access to receive education, training, health care services, rehabilitation services, preparation for employment and recreation opportunities in a manner conducive to the child de $^{\mathrm{s}}$ achieving the fullest possible social integration and individual development, including his or her cultural and spiritual development.e Learners without disabilities have little problems, if any, in integrating in the society but can be a real challenge for a learner with disabilities where, most often, people's expression at a sight of a person with disability is almost always negative. The ,Salamanca Statement and Framework for Action" (1994) asserts that „Regular schools with inclusive orientation are the most effective means of combating discrimination, creating welcoming communities, building an inclusive society and achieving education for alle(article 2).

The statement further says that "inclusion and participation are essential to human dignity and to the enjoyment and exercise of human rights ${ }^{\text {ee }}$ (Salamanca Statement, 1994). The Jomtien (Thailand) World Conference on Education for All (EFA) (1990) and the Dakar Framework for Action (2000) set the goals for Education for All (EFA) with a strong emphasis on inclusive education. The international instruments give an outline of what is to be done but does not zero in to the actual classroom situations. It is left to member states who signed these protocols to work out its own implementation strategies. In a joint report, Cameroon and UNESCO (2004/2005) observed that the instruments are geared towards "enabling national and regional policies that restructure education systems to accommodate inclusion through the provision of resources, mobilization of all stakeholders and creating partnerships with other organizations. " Cameroon therefore has to develop its programme of action in line with its local situation in order to fully implement inclusive education policy. The literature reviewed therefore is in line with inclusive education, based on the determinants of implementing inclusive education in Cameroon which up till date is more of a dream than reality.

\section{Learners without disabilities and implementation of inclusive education}

A regular school intending to go inclusive must prepare the school well for such an undertaking. The school here refers to the teachers, pupils, parents and the school non-teaching staff. This is critical if the policy of inclusive education is to succeed in such a school. The learners in particular are sensitive and can easily reject the new learners particularly when they realize that they have disabilities. Acceptance by the school community is therefore paramount. The learners should be able to understand the type of learners they are going to intermingle with on an everyday basis in the classrooms, in the playfields and within the school compound. They need to know what is expected of them and what they expect from the learners to be admitted; for example the learners will need mutual respect from one another. Hegarty (1981) says that "learners (without disabilities) should be helped to see that individuals differ in many ways and that disabilities are not the uniquely distinguishing characteristics that they are often supposed to be." Once these learners know their colleagues well, they will have no problem interacting with them.

\section{School infrastructure and implementation of} inclusive education

This section looks at the influence of school infrastructure in the implementation of inclusive education in the South West Region Of Cameroon. The infrastructure alluded to here include the classroom designs, toilets and the school compound.

\section{Classroom designs}


One of the basic principles of inclusion is for the child with special needs and disabilities to attend the school nearest to the home, which, as UNESCO puts it, the school that would be attended if the child had no disability.(Salamanca Statement for Action, 1994). This therefore means that the school must anticipate and prepare for children with different kinds and levels of disability. In effect the school should be restructured which will include the classroom designs. UNESCO, (1994), asserts that ,changes in all the following aspects of schooling, as well as many others, are necessary to contribute to the success of inclusive schools: curriculum, buildings, school organization..." However, Hegarty (1981) cautions and asserts that "the needs of all pupils must be balanced." The restructuring of the classrooms should include wide doors, spacious to allow for free movement of learners on wheelchairs, crutches, and cerebral palsy cases. Classroom entrances should have ramps for accessibility by those on wheelchairs. The lighting system should also be proper to allow for learners who may be included and have low vision problems.

\section{School compound}

The school compound should be disability friendly. This will allow learners with disabilities to access any part of the school, like the playgrounds, the libraries and other facilities within the school compound necessary for their comfort in the school. The school should ensure that every entry to a building has an access ramp for those on wheelchairs. The school paths should have murram, if not tracked for ease of learners ${ }^{\text {ee }}$ movement.

Without the school compound being made disability friendly, it could make the life of a learner with disability very difficult which may result in dropout. Hegarty (1981) says that "all pupils need places in a school where they can relax over chosen activities, whether this is physically letting off steam, chatting with friends or taking part in organized club activities. If some pupils do not have access to such places, then they do not participate fully in the social life of the school." this therefore means that all areas of the school should be welcoming to the learner who has been included.

\section{Toilets}

Toilets, like classrooms should also be restructured to allow for use by learners with disabilities. This may include wide toilet doors, rails on the sides of the toilet walls as well as rails beside the toilet basin as well as the bathing area in case of a boarding school. It must be noted that the changes or restructuring should not disadvantage learners without disabilities. The school can have at least one toilet for the boys and one for the girls restructured to accommodate the necessary changes and not all the toilets. In its report of the taskforce on implementation of Free Primary Education, stated that "there was need to build adapted toilets to assist the children to hold onto while toileting ${ }^{\text {ee }}$ in the national territory of Cameroon.

\section{Support services and implementation of inclusive education}

Support services refers to efforts aimed at supporting both the teacher and the student enrolled in an inclusive setting to ensure that students benefit fully and maximize their potential abilities. Ainscow, (1999) states "given that any child may experience some difficulty that causes concern at some stage of their school life, it makes sense that forms of support should be available as and when necessary. "e The support services envisaged in this study are categorized into two: direct support to pupils and the teacher though are hardly available.

\section{Direct support services}

The direct support services are those that assist the learner directly as an individual whether in the classroom or outside the classroom. The direct support services may take any of the following forms:

Children supporting themselves - Children provide what can be described as "naturale form of support. They sit together, work out problems together in groups or even in practical work. This happens whether the teacher is present or not.

Resource room - Is a room in a regular school which is equipped for enriching learning for learners with special education needs. It is managed by a resource teacher who is trained in special needs education (Jenkinson, 1997).

Peripatetic or Itinerant teacher - Is a teacher who moves between schools and homes teaching, training, counseling and providing materials to teachers (and sometimes to parents) and children themselves.

Guidance and counseling. This is mainly intended for children who have special needs and disabilities and also to their parents. This is intended to ameliorate the effects of disability on the learner and the parent. This is given by trained education counselors or the medical personnel. 
$>$ Medical practitioners - Provide medical care to children with special needs and disabilities. They can also advise on intervention, prevention and placement of these children in schools. They work together with other relevant professionals as members of the interdisciplinary team.

$>$ Classroom support through teacher aide. The teacher aide assists the classroom teacher particularly where learners with severe disabilities have been included. This could be in accessing books, writing material or even mobility within the classroom.

$>$ Financial support. This could be assistance directly to schools which have enrolled students with special needs and disabilities. This could be by individuals or even Non- Governmental organizations among others. The support services to all learners, with or without disabilities in an inclusive school/classroom are important for the success of an inclusive education programme. Even thou support is usually available, it is not adequate. Usually there is only one teacher serving a number of schools in a whole district. The demand for such services sometimes overstretches the service provider.

\section{Teacher Preparedness and implementation of Inclusive Education}

The successful interaction and delivery of a teacher in the classroom consistently will depend on how well the teacher has been prepared professionally.

\section{Teachers' qualification}

Teacher qualification is another important resource critical to the success of inclusive education, just as the direct support services alluded to above. An understanding of special needs and disabilities is necessary in addition to knowledge of general education. This will enable the teacher to tackle the various challenges that will arise in the course of duty as there are no outright answers to emerging issues both in and out of the classroom. Ainscow (1999) says that appropriate qualifications "lead to a greater sense of confidence and empowerment, and an increased willingness to experiment with alternative responses to problems experienced in the classroom. ${ }^{\text {e }}$

In addition to appropriate qualifications, teachers need and benefit from additional in- service training which gives them "increased knowledge about curricular and instructional modifications together with practical skills in adapting curriculum content and resource materials (Westwood, 1997). Westwood further argues that ,if inclusive practices are to be the norm, teachers need to know how classroom instruction can be differentiated according to student's characteristics. Successful inclusion will depend very heavily upon teacher's skills in developing differentiated practices. "e Jenkinson (1997) adds „teachers may feel threatened by having to cope with a child who has special needs that they feel illequipped to deal with, while at the same time providing instruction for as many as thirty other students who also have a wide range of individual needs and abilities. Lukong (2016) observation reflects the situation in the South West Region of Cameroon schools where overcrowded classes demand extra abilities and skills from the teacher. In such a situation, and in the absence of the skills, the learner with disabilities will either be ignored or neglected. It is therefore of utmost importance to develop teacher skills in order to successfully implement a programme of such magnitude. The success or failure of such a programme as inclusive education is almost entirely dependent on the teacher.

The highest qualification in the teachers is categorized into Certificate, Diploma, Bachelors, Masters or Doctoral degrees. A number of studies have examined the ways in which teachers ${ }^{\text {ee }}$ highest qualifications are related to students ${ }^{\text {ee }}$ achievement. Many of the studies found that teachers ${ }^{c}$ qualifications correspond positively with students ${ }^{e e}$ achievement. For instance, Betts, Zau, \& Rice (2003) found that teachers ${ }^{\text {ee }}$ highest degree correlates positively with students ${ }^{\text {ee }}$ achievement. Rice (2003) found that when teachers have an advanced degree in their teaching subjects it will have a positive impact on the students ${ }^{\text {ee }}$ achievements. Greenwald, Hedges, and Laine (1996) conducted a meta-analysis of studies that examined the relationship between school resources and student achievement; they found that there was a significant and positive relationship between teachers ${ }^{\text {ee }}$ qualification measured as having a master's degree or not having a master's degree and students ${ }^{\text {ce }}$ achievement. Goldhaber and Brewer (1996) indicated that an advanced degree that was specific in the subject taught was associated with higher students ${ }^{\text {ee }}$ achievement.

\section{Teachers' subject majors}

The importance of the link between teacherse ${ }^{\text {se }}$ subject majors and students ${ }^{\text {ee }}$ achievement have repeatedly been acknowledged by leading education groups such 
as the Education trade Unions (Thomas \& Raechelle, 2000). Several other studies in the teacher preparation research have also shown a positive connection between teachers ${ }^{\text {ee }}$ subject majors and students ${ }^{\text {ce }}$ achievement. For example, Wilson and Floden (2003) found that students of mathematics teachers with mathematics or mathematics education degrees demonstrate higher academic achievement in mathematics. However, they also indicated that there might be a limit at which more mathematics knowledge does not help the teacher. Goldhaber and Brewer (1996) found that specialisation in one's teaching subject is the most reliable predictor of students $^{\text {ee }}$ achievement. A review of a study of high school studentse performance in mathematics and science by Darling-Hammound (2000) found that one having a major in his/her teaching subject was the most reliable predictor of students ${ }^{\text {ee }}$ achievement scores in mathematics and science. Similarly, Wenglinsky (2002) and Greenberg, et al. (2004) said that mathematics teachers having a major in mathematics correlated with higher students ${ }^{\text {ee }}$ achievement in mathematics. However, a few other researchers reported inconsistent relationships between teachers ${ }^{c e}$ subject majors and students $^{\text {ee }}$ achievement. For example, Ingvarson et al. (2004) reported that a number of studies on the relationship between teachers ${ }^{\text {ee }}$ subject majors and student's achievement in mathematics reported complex and inconsistent results. Similarly, Martin et al. (2000) and Wenglinsky (2000) found that having a major in mathematics was not associated with teacher effectiveness.

\section{Teachers' teaching experience}

A number of studies found teachers ${ }^{e}$ years of experience to positively correlate with students ${ }^{\text {ce }}$ achievement. For example, Betts et. al. (2003) found that teachers ${ }^{\text {ee }}$ experience significantly correlates with students $^{\text {ee }}$ achievement in mathematics. A report by the Centre for Public Education (2005) stated that research has been consistent in finding positive correlations between teaching experience and higher students ${ }^{\text {ee }}$ achievement. Teachers with more than five years teaching experience are found to be the most effective while inexperience is shown to have strong negative effect on students ${ }^{\text {ee }}$ performance. Greemwald, Hedges, and Laine (1996) in their metaanalysis of data from 60 studies found that teachers ${ }^{\text {ee }}$ years of teaching experience positively correlates with students $^{\text {ee }}$ achievement. In a related finding, Rivkin, Hanushek, \& Kain (2005) showed that students of experienced teachers achieved better than students of new teachers (those with one to three years of experience).

Similarly, some other studies, for example Rosenholtz, (1986) quoted in Darling- Hammond (2000), and Hawkins, Stancavage, \& Dossey, (1998) found teaching experience to be related to students ${ }^{\text {ee }}$ achievement but that the relationship may not be linear; students of teachers who had fewer than five years of experience The implication of that is that the benefit of experience levels off after five years. The curvilinear effect according to Darling-Hammond (2000) could be because older teachers do not continue to grow and learn and may grow tired of their jobs. Had lower levels of mathematics achievement but there were no difference in mathematics achievement among students whose teachers had more than five years of experience.

\section{Monitoring and evaluation and implementation of inclusive education}

In order to ensure the success of the programme, it is important that monitoring is done frequently and an evaluation carried out to ensure that it is on course. It is also learning experiences for all that are involved and such monitoring and evaluation generates more knowledge for correction and future improvement of the programme either in Cameroon or elsewhere.

\section{Implementation of inclusive education}

Even when a programme has been planned in detail and implemented with care, it will be necessary to monitor the programme in action not only to ensure that it is on target and objectives are being met but also to take account of emerging developments. It is important to note that this monitoring is for both individual pupils progress and the development of the programme as whole. Hegarty (1981) emphasizes that ,the adequacy of support for ordinary teachers, the amount of classroom integration that is possible, the need for involvement of external The monitoring could be done jointly by a team within the school, or a team involving staff from the schools that are implementing the inclusive programme and also the Ministry of education officials involved in the programme, preferably quality assurance officers. This will ensure that issues are tackled appropriately as they arise and also keep the programme on course. support and many other factors need to be scrutinized in light of experience. 


\section{Inclusive Education Policy}

Inclusive education, like any other school programme will succeed well if there exists a policy to support and guide it. This will ensure that the resources necessary for its successful implementation are provided. Policy will give the direction to take and will compel schools to accept learners with special needs and disabilities.

The Salamanca Statement and Framework for Action (UNESCO,1994) recognized the importance of policies and went on to say that "educational policies at all levels, from the national to the local, should stipulate that a child with a disability should attend the neighbourhood school, that is, the school that would be attended if the child did not have a disability." Loxley and Thomas (2001) assert that ,inclusion cannot... be effected simply on the basis of the way that teachers and academics conceptualize differences, it is part of a complex wider picture." Policy also would address discrimination along the lines of race, gender or disability. further say that „whether we like it or not it is impossible to avoid policy. We can ignore it, extend it, subvert it, rewrite it but not escape it." Paul et al (1997) also contend that policy would ensure that specific rules and standards would be established that would maximize the learning environment and instruction."

\section{THEORETICAL PERSPECTIVES}

\section{Disability Theories}

Disabled Peoples International - DPI (1981) made a clearly differentiated the definition between disability and impairment: disability is the loss or limitation of opportunities to take part in the normal life of the community on an equal level with others because of physical and social barriers; impairment is the functional limitation, within the individual caused by physical, mental or sensory impairment (Anderson, 2013). These definitions are very fundamental in Definitions are central to appreciating the theories of disability and impairment.

\section{The Medical model}

According to the medical model, people with special needs are visible only as patients, welfare or charity cases (Hales, 1996). This medical model views what ought to be wrong with people with physical disabilities rather than what they need, thus affecting their participation, mobility, loss of independence and social competence. The medical model considers

\section{The Social model of disability}

The social models' view concerns the relationship between an individual and the social environment. The social model of disability contends that much of the barriers faced for example by students with physical disabilities in secondary schools of Cameroon are caused by society being designed to address the needs of non-disabled students. In their effort to change society's perception of disabilities, Persons with disabilities have made a lot of writings and clearly indicated where the limitation lies, not in the individual, but society's restrictions for example, in terms of negative attitude and physical barriers. According to Oliver (1996), this view is known as the social model of disability, or social oppression theory. Although this theory respects the value of scientifically based medical research, it emphasizes the social theories of disability of research to improve the quality of disabled people's lives (Oliver, 1996).

The social model of disability defines environment as an enabling and disabling factor. Steinfield and Danford (1999) argue that, the physical environment can be regarded as part of disability because in addition to social barriers (for example attitudes and policies that lead to inaccessible places), it restricts people to participate in various activities. For example, environmental barriers at work, home, school or community setting can affect the individual's abilities. The environment plays an important role in the social model of disability because it reveals how environmental designs (i.e., physical and social) re-enforce stereotype of helplessness associated with disability thus focusing on the person to the exclusion of the environment.

The approach to social model provides that, once social barriers to reintegration of people with physical impairment are removed, the disability itself is eliminated (Shakespeare, 2006). The requirements should be changes to environment and its control systems in addition to social roles and attitudes in the whole community. On the other hand, communication and architectural barriers are easier to remove than the social and economic barriers. Albrecht, Seelman and Bury (2001) argue that the social model considers disability as the loss or limit of opportunities of participating in community life as a result of social and physical barriers. The social model has therefore, replaced the individual or medical model which considers people with special needs to be visible only as patients, clients, or welfare/ charity cases under the 
control of medical or other disability-related professionals, and the invalidity of the individual as the course of disability (Hales, 1996).

\section{Medical Model Vs Social Model}

There are several disability theories. This study is mainly grounded in the Social model of disability in contrast to the Medical models as indicated below: The medical model of disability would consider a student with physical disabilities as a problem to which nobody is responsible except the individual himself or herself. For instance, the medical model would regard the problem to be the wheel chair and not the inaccessible toilet where a student who uses a wheel chair cannot access a toilet due to the narrow door, limited interior space and steps at the entrance. On the other hand, the social model would consider the inaccessible toilet to be the obstacle due to poor architectural design which can be improved upon by the society and not the student with a physical impairment.

According to the medical modal, the barriers faced by students with physical disabilities in secondary schools like limited space between classroom furniture, stepped entrances, stony and rugged paths, narrow corridors and doors etc should be borne by the students with physical disabilities who should also devise ways of coping without bothering others. On the other hand, the social modal is encompassing and all inclusive with provisions like adaptations or modifications to facilitate the full participation, mobility, social competence and independence of students with physical disabilities.

\section{Recommendations}

The following were the recommendations of this conceptual and policy implication paper:

$>$ The study recommends that the government should provide the necessary resources and facilities for inclusive education in primary schools. This will facilitate effective implementation of inclusive education in schools.

$>$ The study also recommends that teachers should be trained and/or given in-service courses on inclusive education. This will give them the skills and knowledge in handling pupils with or without special needs thus promoting inclusive education.

$>$ The study finally recommends that support services for pupils with special education should be improved. This will promote the implementation of inclusive education as pupils in need of special support will get access to the services thus promoting the implementation of inclusive education.

\section{Concluding Remarks}

Inclusion is a process of addressing and responding to the diversity of needs of all learners through increased participation in learning. After the Salamanca conference of 1994 in which Governments were called upon to ,give highest policy and budgetary priority to improve their education systems to enable them to include all children regardless of individual difference or difficultiese and to "adopt as a matter of law or policy the principle of inclusive education, enrolling all children in regular schools unless there are compelling reasons for doing otherwise (UNESCO, 1994), the government of Cameroon have not adopted and implemented the protocol. This has not necessitated the schools to be ready for all children regardless of their disability. Inclusion therefore required changes and modifications in content, approaches, structures and strategies with a common vision which covers all children of the appropriate age range and a conviction that it is the responsibility of the regular system to educate all children. How ready is the Cameroonian system to implement this? Governments that signed the protocols were required to develop their own strategies for implementation. In Cameroon no inclusive education policy is in place and many programmes have not been implemented in selected schools in the South West Region of Cameroon.

Some of these requirements include; availability of teaching/learning resources, teachers being trained on appropriate instructional methods (to handle inclusive classrooms), teachers with the right qualification being hired, provision of support services like those of itinerant teachers and availing physical facilities which should be disability friendly and in addition to the entire school environment being disability friendly. Although most researchers in this field agree on the need for inclusion and the necessary requirements for that, none has delved on the possible remedial measures in case a programme comes up against difficulties as is experienced in the South West Region of Cameroon. This study therefore seeks to establish the possible efforts and challenges affecting the smooth implementation of the inclusive programme in the South West Region of Cameroon. 
International Journal of Trend in Scientific Research and Development (IJTSRD) ISSN: 2456-6470

\section{References}

1) Ainscow, Mel. (1999). Understanding the development of Inclusive Schools. London. Falmer Press.

2) Betts, J. R., Zau, A. C., \& Rice, L.A. (2003). Determinants of student achievement: New Evidence from San Diego. San Francisco, CA: Public Policy Institute of California.

3) Coutinho, M. and Repp, A.C. (1998/1999). Inclusion. The Integration of Students with Disabilities. Belmont, California. Wadsworth Publishing Co.

4) Darling-Hammond, L. (2000). Teacher quality and student achievement: A review of state policy evidence. Education Policy analysis Archives, $8(1), 1-44$.

5) Frederickson, N \& Cline, T. (2002). Special Educational Needs, Inclusion and Diversity: A Textbook. Buckingham: Open University Press.

6) Gary, Thomas \& Vaughan, Mark. (2004). Inclusive Education. Readings and Reflections. Berkshire, England. Open University Press.

7) Gary, Thomas \& Vaughan, Mark. (2004). Inclusive Education. Readings and Reflections. Berkshire, England. Open University Press.

8) Goldhaber, D. D., \& Brewer, D. J. (1996). Evaluating the effect of teacher degree level on educational performance. Washington, DC: NCES.

9) Goldhaber, D. D., \& Brewer, D. J. (1996). Evaluating the effect of teacher degree level on educational performance. Washington, DC: NCES.

10) Greemwald, R., Hedges, L. V., \& Laine, R. D. (1996). The effect of school resources on student achievement. Review of Educational research, 66(3), 361-396.

11) Ingvarson, L.; Beavis, A.; Bishop, A.; Peck, R., \& Elsworth, G. (2004). Investigation of Effective Mathematics teaching and Learning in Australian Secondary Schools. Australia: Australian Council for Educational Research.

12) Jenkinson, J.C. (1997). Mainstream or Special? Educating students with disabilities, London. Routledge Publishing co.

13) Loaiza, E., \& Cappa, C. (2005). Measuring Children's Disability via Household Surveys: The
MICS Experience: Paper presented at the 2005 Population Association of America (PAA) meeting March 30 - April 2, 2005. Philadelphia, New York: UNICEF.

14) Martin, M. O., Mullis, I. V. S., Gregory, K. D., Hoyle, C., \& Shen, C. (2000). Effective Schools in Science and Mathematics. Chestnut Hill, MA: International Study Centre, Boston College.

15) Mayer, E. J. E. (2007). Study on the rights of persons with disabilities in Cameroon. York University: Disability Rights Promotion International.

16) Paul, J.L.et al. (1997). Special Education Practice. Applying the Knowledge, Affirming the Values, and Creating the Future. Pacific Grove California. Brooks/Cole Publishing Co.

17) Rioux, M. H., Marks, L. A. B., \& Basser L. A. (2011). Critical Perspectives on Human Rights and Disability Law. MA, Danvers: Martinus Nijhoff Publishers.

18) Rivkin, S. G., Hanushek, E. A., \& Kain, J. F. (2005). nTeachers ${ }^{\text {ee }}$ schools, and academic achievement. Econometrica, 73 (2), 417-458.

19) Tani. E. Lukong (2016) Indigenous Peoples Education: Priorities for Inclusive Education, the Case of Cameroon. Published in the African Journal of social Sciences'. Volume 6, Number 4 May, 2016 http://dx.doi.org/10.20431/24547654.0203003. www.arcjournals.org

20) Tani. E. Lukong and N. Nformi Doris(2016) Inclusive Education in Cameroon; Dictates of Learning

Environment on the Academic Participation of Students with Physical Disabilities in the South West Region of Cameroon, International Journal of History and Cultural Studies (IJHCS) Volume2, Issue 3, 2016, PP $28 \quad-47$ http://dx.doi.org/10.20431/2454-7654.0203004. www.arcjournals.org

21) Thomas, S., \& Raechelle, F. (2000). The National Council on Teacher Quality: Expanding the Teacher Quality Discussion. Washington DC: ERIC.

22) UN (2006). The Convention on the Rights of Persons with Disabilities-UNCRPD,

23) UN (2006). The Convention on the Rights of Persons with Disabilities-UNCRPD, 
24) UN (2009). The World Population Prospects. New York: Population Division.

25) UNESCO (1994). Salamanca Framework for Action. Paris: UNESCO.

26) UNESCO (2013). UNESCO Global Report: Opening New Avenues for Empowerment: ICTs to Access information and knowledge for persons with disabilities. Paris: UNESCO publications.

27) UNESCO.(1994). The Salamanca Statement and Framework for Action on Special Needs Education.Paris: UNESCO.

28) UNICEF (2008). Monitoring Child Disability in Developing Countries: Results From the Multiple Indicator Cluster Surveys. NY, New York: United Nations Children's Fund, Division of Policy and Practice.

29) United Nations (1993). United Nations Standard Rules on the Equalization of opportunities for persons with disabilities. New York: United Nations.

30) Waldron, Karen, A. (1996). Introduction to Special Education: The Inclusive Classroom. New York: Delmar Publishers Inc.

31) Westwood, P. (1997). Commonsense Methods for Children with Special Needs. London: Routledge Falmer.

32) Wilson, S. M., \& Floden, R. E. (2003). Creating effective teachers: concise answers to hard questions. Washington: American Association of Colleges of Teacher Education.

33) www.un.org/disabilities/. Retrieved $2^{\text {nd }}$ January, 2014.

34) www.un.org/disabilities/. Retrieved $2^{\text {nd }}$ January, 2014. 